\title{
The potential for increasing nitrogen responses using Agrotain treated urea
}

\author{
J.D. BLENNERHASSETT ${ }^{1}$, B.F. QUIN ${ }^{2}$, M. ZAMAN ${ }^{1}$ and C. RAMAKRISHNAN ${ }^{1}$. \\ ${ }^{1}$ Summit-Quinphos (NZ) Ltd, P.O. Box 24020, Auckland, New Zealand \\ ${ }^{2}$ Quin Environmentals (NZ) Ltd, P.O. Box 125-122, Auckland, New Zealand \\ jamieb@sq.co.nz
}

\begin{abstract}
Two trials were set up near Te Awamutu and Ashburton to explore the difference in pasture responses between standard urea and Agrotain treated urea (SustaiN) over a 12 month period. Two rates of nitrogen $(\mathrm{N})$ application were used (30 kg N/ha and $60 \mathrm{~kg} \mathrm{~N} / \mathrm{ha}$ ) and the fertilisers were applied four times throughout the year (once each "season"). At the $30 \mathrm{~kg} \mathrm{~N} / \mathrm{ha}$ application rate $(120 \mathrm{~kg} \mathrm{~N} /$ ha total), $\mathrm{N}$ responses with SustaiN were $75.2 \%$ higher than with urea alone. At the $60 \mathrm{~kg} \mathrm{~N} / \mathrm{ha}$ application rate $(240 \mathrm{~kg} \mathrm{~N} / \mathrm{ha}$ total), $\mathrm{N}$ response with SustaiN was $33.7 \%$ higher than urea alone. Similar seasonal and annual responses occurred at both sites. Economic analyses showed these increases in response to be very profitable and indicate that there is considerable potential for improving farm production and profitability by treating urea with Agrotain.
\end{abstract}

Keywords: nitrogen, urea, Agrotain, pasture, response, efficiency

\section{Introduction}

In developed pastoral systems, nitrogen $(\mathrm{N})$ is generally the nutrient that poses the greatest limitation to pastoral yield. Ball \& Crush (1985) commented that even the highest $\mathrm{N}$-fixing clover/ryegrass pasture will generally respond to an application of $\mathrm{N}$ fertiliser. Recognition of this fact by farmers, coupled with good commodity prices, has resulted in a $670 \%$ increase in urea use on sheep and beef farms and $160 \%$ on dairy farms between 1996 and 2002 (Parliamentary Commissioner for the Environment 2004).

Traditionally, responses of only $10-15 \mathrm{~kg} \mathrm{DM} / \mathrm{kg} \mathrm{N}$ are expected on developed pastures in New Zealand, despite the fact that this represents conversion of only $35-50 \%$ of the applied $\mathrm{N}$ fertiliser into additional dry matter. This means that a large percentage of the $\mathrm{N}$ fertiliser input is essentially being wasted. This lack of efficiency has been attributed to a number of factors including volatilisation, leaching and immobilisation, companion ions, $\mathrm{pH}$, pasture age and species (Ball \& Field 1982; Quin et al. 2006).

If the efficiency of urea could be improved at reasonable cost by either reducing losses and/or modifying other factors controlling the response, significant gains in production and farm profitability would be achievable. One approach, shown to be effective overseas, is the treating of urea fertiliser with the urease inhibitor $\mathrm{N}$-(n-butyl) thiophosphoric triamide (NBPT), trade name Agrotain ${ }^{\circledR}$ (Watson 2000).

Urea-N is particularly susceptible to losses as ammonia gas after it has undergone hydrolysis. The hydrolysis is facilitated by the urease enzyme which occurs naturally in soils and on the surface of plant leaves and is usually complete within $2-3$ days. Ammonia losses occur principally in the first 10 days after application of urea. Urease inhibitors temporarily block the action of the urease enzyme, thereby slowing the process of urea hydrolysis by $1-2$ weeks. The effect of this is that the $\mathrm{N}$ is held in urea form for a longer period, which reduces the increase in $\mathrm{pH}$ around the fertiliser granule as well as decreasing the amount of ammonium in the soil, thereby reducing the potential for volatilisation losses.

In addition to reducing ammonia volatilisation, treatment of urea with Agrotain has been shown to reduce nitrate leaching, as an indirect result of the reduction in the rate of availability of ammonium-N for conversion into nitrate (Zaman et al. 2004). Furthermore, Quin et al. (2006) postulated that the conversion of urea to ammonium-N and nitrate-N increases the opportunity for direct uptake of urea and ammonium-N by the plant, saving energy for additional growth and nutrient uptake by roots.

This paper presents data from two New Zealand field trials investigating the effect of treating urea fertiliser with a urease inhibitor (Agrotain) on pasture production over a 12 month period and presents cost-benefit calculations.

\section{Materials and Methods}

The two trials were set up near Te Awamutu (North Island) and Ashburton (South Island) on dairy pastures. Pasture production was measured over a 12 month period. Both trials contained five treatments (untreated control, urea at 30 and $60 \mathrm{~kg} \mathrm{~N} / \mathrm{ha} /$ application, and Agrotain treated urea (SustaiN) at 30 and $60 \mathrm{~kg} \mathrm{~N} / \mathrm{ha} /$ application). Each treatment was applied four times throughout the year (once each "season") giving two total N application rates of $120 \mathrm{~kg} \mathrm{~N} / \mathrm{ha} / \mathrm{yr}$ or $240 \mathrm{~kg} \mathrm{~N} /$ $\mathrm{ha} / \mathrm{yr}$. Each treatment was replicated three times on plots of $2 \times 2 \mathrm{~m}$ and laid out in a randomised block design. Prior to the application of fertiliser, the plots were 
mowed to leave residual masses of approximately 1200 $\mathrm{kg} \mathrm{DM} / \mathrm{ha}$. Fertiliser was then applied and the pasture was cut back to this level once pasture covers on the fastest growing plots reached grazing mass $(3000 \mathrm{~kg}$ $\mathrm{DM} / \mathrm{ha}$ ). This occurred twice after each fertiliser application (except for the first application where there were three cuts taken), before the treatments were reapplied and the procedure repeated. Fertiliser application dates are shown in Table 1. Once cut and weighed, a sample of the pasture was taken and analysed for dry matter and $\mathrm{N}$ content. Approximately $50 \%$ of the pasture clippings were returned to the plot after each harvesting. This was considered to approximate nutrient return under grazing more closely than full clippings return, and thus allow for more meaningful calculations of total dry matter production, nitrogen response and nitrogen uptake over the full year's duration of the trials.

\section{Statistical analysis}

ANOVA was carried out on pasture yield and $\mathrm{N}$ uptake for each individual fertiliser application as well as for the entire 12 month period. Least significant difference (LSD) values at $\mathrm{P}<0.05$ were calculated when the treatment effect was significant.

\section{Results}

On an annual basis, the differences between SustaiN and urea are statistically significant at both rates and at both sites (Tables 2 and 3). At the $30 \mathrm{~kg}$ application rate (120 kg N/ha annually), SustaiN produced $1872 \mathrm{~kg}$ $\mathrm{DM} / \mathrm{ha}$ and $1447 \mathrm{~kg} \mathrm{DM} / \mathrm{ha}$ more than urea at the Te Awamutu and Ashburton sites respectively. At the $60 \mathrm{~kg}$ $\mathrm{N} / \mathrm{ha}$ application rate $(240 \mathrm{~kg} \mathrm{~N} / \mathrm{ha}$ annually), the differences between SustaiN and urea (1423 kg DM/ha and $1326 \mathrm{~kg} \mathrm{DM} / \mathrm{ha}$ at the Te Awamutu and Ashburton sites respectively) were very similar to those achieved at the lower application rate. Within seasons, while the differences achieved statistical significance on only 7 out of 16 comparisons (Tables 2 and 3), the trend is for production with SustaiN to exceed that with urea in all seasons, except at the high $\mathrm{N}$ rate at Te Awamutu in summer.

The average $\mathrm{N}$ response efficiencies (difference between the dry matter produced by the various fertiliser treatments and the control, divided by the amount of $\mathrm{N}$ applied) on the urea treatments were 19.4 and $22.3 \mathrm{~kg}$ $\mathrm{DM} / \mathrm{kg} \mathrm{N}$ at the Te Awamutu and Ashburton sites respectively, with a slightly higher response efficiency achieved with lower rates of application. The $\mathrm{N}$ response efficiencies measured on the SustaiN treatments were much higher, 30.1 and $30.0 \mathrm{~kg} \mathrm{DM} / \mathrm{kg}$ $\mathrm{N}$ (averaged over the two $\mathrm{N}$ rates) at the Te Awamutu and Ashburton sites respectively, with the highest efficiencies being achieved at the lower application rates. Overall, Sustain improved the $\mathrm{N}$ response efficiencies compared to urea by $44.2 \%$, with higher efficiency gains at lower application rates $(75.2 \%$ against $33.7 \%$ for the 30 and $60 \mathrm{~kg} \mathrm{~N} / \mathrm{ha}$ application rates respectively). There was no clear seasonal pattern to the percentage improvements achieved by SustaiN in comparison to urea, with increases tending to occur across all seasons.

The herbage $\mathrm{N}$ uptake data (Tables 4 and 5) follows a similar but less marked and more variable pattern to the dry matter production, with generally higher $\mathrm{N}$ uptakes on the SustaiN treatments than on the urea treatments. There are some anomalies at the high $\mathrm{N}$ applications. The differences between annual N uptake with SustaiN and urea are statistically significant for the Ashburton site only, with the $30 \mathrm{~kg} \mathrm{~N} / \mathrm{ha}$ rate nearly achieving significance at the Te Awamutu site.

Calculations of apparent fertiliser-N uptake efficiency (defined as the difference in $\mathrm{N}$ uptake between the fertiliser treatment and the control as a percentage of the amount of $\mathrm{N}$ applied), showed substantial differences between the sites. The urea and SustaiN treatments took up around $70 \%$ and $85 \%$ of the applied fertiliser respectively at the Te Awamutu site, whereas at the Ashburton site only $41 \%$ and $55 \%$ was taken up. This is despite the fact that the $\mathrm{N}$ response efficiencies were similar at both sites. It should be noted that the Ashburton site was only converted to dairying 5 years ago, and is therefore likely to still be accumulating soil organic matter, with a consequent higher rate of fertiliser $\mathrm{N}$ immobilisation.

\section{Discussion}

The $\mathrm{N}$ response efficiencies obtained with urea, 19.4 and $22.3 \mathrm{~kg} \mathrm{DM} / \mathrm{kg} \mathrm{N}$ at the Te Awamutu and Ashburton sites respectively, are higher than average but still consistent with the range of responses found by other researchers in New Zealand (Ball \& Field 1982).

The two trials demonstrate that there is considerable potential for improving the production of pastoral farms by using SustaiN instead of standard urea. The size of the average fertiliser efficiencies with SustaiN at both sites, and even the fact that larger increases are achieved at the lower application rate with no particular seasonal trends, are remarkable. Before the commencement of the trial, it was thought that increases in pasture production achieved with Sustain were likely to come predominantly from reductions in volatilisation, which were likely to be greatest at higher application rates and in warmer drier months (Black et al. 1985). Estimates for typical volatilisation losses from urea fertiliser in New Zealand range from $5-25 \%$ (Theobald \& Ball 1984; Black et al. 1985; Ledgard et al. 1999), so any increase in pasture $\mathrm{N}$ response as a result of reductions 
Table 1 Fertiliser application dates.

\begin{tabular}{|c|c|}
\hline Te Awamutu & Ashburton \\
\hline Application 1: 03-Jan-2005 (Summer) & Application 1: 08-Dec-2004 (Summer) \\
\hline Application 2: 14-Apr-2005 (Autumn) & Application 2: 04-Apr-2005 (Autumn) \\
\hline Application 3: 03-Aug-2005 (Winter) & Application 3: 19-Aug-2005 (Winter) \\
\hline Application 4: 18-Oct-2005 (Spring) & Application 4: 03-Nov-2005 (Spring) \\
\hline
\end{tabular}

Table 2 Average pasture yield ( $\mathrm{kg} \mathrm{DM} / \mathrm{ha}$ ) and $\mathrm{N}$ response efficiency $(\mathrm{kg} \mathrm{DM} / \mathrm{kg} \mathrm{N})$ at Te Awamutu.

\begin{tabular}{lccccrc}
\hline Treatment & Summer & Autumn & Winter & Spring & Annual & $\begin{array}{c}\text { N Response } \\
\text { Efficiency }\end{array}$ \\
\hline Control & 2603 & 757 & 2871 & 2791 & 9022 & \\
Urea @ 30kg N/ha & 3385 & 956 & 3599 & 3507 & 11447 & 20.2 \\
SustaiN @ 30kg N/ha & 4008 & 1432 & 4002 & 3877 & 13319 & 35.8 \\
Urea@60kg N/ha & 4113 & 1296 & 4133 & 3923 & 13465 & 18.5 \\
SustaiN @60kg N/ha & 4088 & 1492 & 4810 & 4498 & 14888 & 24.4 \\
LSD 5\% & 975 & 341 & 482 & 689 & 924 & \\
\hline
\end{tabular}

Table 3 Average pasture yield (kg DM/ha) and $\mathrm{N}$ response efficiency (kg DM/kg N) at Ashburton.

\begin{tabular}{lcccccc}
\hline Treatment & Summer & Autumn & Winter & Spring & Annual & $\begin{array}{c}\text { N Response } \\
\text { Efficiency }\end{array}$ \\
\hline Control & 6169 & 1383 & 2139 & 3873 & 13564 & \\
Urea@ 30kg N/ha & 6987 & 1795 & 2500 & 5022 & 16304 & 22.8 \\
SustaiN@ 30kg N/ha & 7511 & 1901 & 2701 & 5368 & 17481 & 32.6 \\
Urea@60kg N/ha & 8141 & 2114 & 2749 & 5794 & 18798 & 21.8 \\
SustaiN@60kg N/ha & 8591 & 2405 & 3082 & 6046 & 20124 & 27.3 \\
LSD 5\% & 316 & 269 & 139 & 809 & 925 & \\
\hline
\end{tabular}

Table 4 Average $\mathrm{N}$ uptake (kg N/ha) at Te Awamutu.

\begin{tabular}{lccrrc}
\hline Treatment & Summer & Autumn & Winter & Spring & Annual \\
\hline Control & 78.2 & 29.6 & 85.0 & 75.0 & 267.8 \\
Urea @ 30kg N/ha & 107.2 & 38.9 & 108.3 & 90.0 & 344.6 \\
SustaiN@ 30kg N/ha & 113.5 & 53.2 & 112.1 & 103.2 & 382.0 \\
Urea @60kg N/ha & 135.9 & 50.8 & 135.3 & 130.0 & 452.0 \\
SustaiN@60kg N/ha & 128.5 & 59.0 & 148.6 & 110.4 & 446.6 \\
LSD 5\% & 34.2 & 12.0 & 18.1 & 16.5 & 38.3 \\
\hline
\end{tabular}

Table 5 Average $\mathrm{N}$ uptake (kg N/ha) at Ashburton.

\begin{tabular}{lccccc}
\hline Treatment & Summer & Autumn & Winter & Spring & Annual \\
\hline Control & 126.1 & 39.1 & 49.1 & 108.1 & 322.5 \\
Urea @ 30kg N/ha & 140.6 & 48.5 & 58.5 & 118.3 & 365.8 \\
SustaiN@ 30kg N/ha & 147.4 & 54.5 & 63.7 & 123.3 & 389.0 \\
Urea @60kg N/ha & 175.1 & 63.3 & 68.3 & 123.6 & 430.4 \\
SustaiN@60kg N/ha & 170.9 & 72.4 & 81.4 & 130.4 & 455.2 \\
LSD 5\% & 16.4 & 6.0 & 6.6 & 9.0 & 20.8 \\
\hline
\end{tabular}


in volatilisation should in theory be within that range. An earlier trial using SustaiN (Zaman et al. 2004), indicated that reductions in volatilisation may not be the only factor improving fertiliser efficiency. These authors measured increases in $\mathrm{N}$ response of $80-93 \%$, despite low volatilisation losses, meaning that reductions in these achieved using Agrotain amounted to only $5 \%$ of the total $\mathrm{N}$ applied. Slowing the hydrolysis of urea has the secondary effect of slowing down nitrification, which in turn reduces nitrate leaching. Zaman et al. (2004) measured a $50-53 \%$ reduction in nitrate leaching with SustaiN, which will have helped increase the amount of $\mathrm{N}$ available for plant growth. However even this is unlikely to have provided enough to account for all the increased production. The size of the responses in that trial and those reported here, suggest that there are other mechanisms which result in substantially better $\mathrm{N}$ responses from SustaiN compared to normal urea.

Quin et al. (2006) postulated that increased efficiency of conversion of $\mathrm{N}$ into protein when taken up as ammonium or urea itself is made possible by using Agrotain. Castle (2004) demonstrated that clover plants at $8^{\circ} \mathrm{C}$ took up significantly more $\mathrm{N}$ in urea form than as nitrate, particularly when these two $\mathrm{N}$ forms were applied to the leaves only. By holding the $\mathrm{N}$ in urea form for much longer, SustaiN is likely to be providing the pasture with a longer window of improved $\mathrm{N}$ uptake, thereby increasing uptake efficiency and reducing the potential for losses to soil processes such as immobilisation. It is known that more energy is required to convert nitrate into amino acids and protein. By providing the plant with a higher portion of the $\mathrm{N}$ as urea and holding it in this form for longer with the Agrotain, less energy will be required by the plant for growth. This energy can be utilised for extra leaf and root growth instead. This in turn provides greater leaf area for producing more energy through photosynthesis and the ability to source extra nutrients through extra root area. This could explain, at least in part, why the low application rate of SustaiN used in this trial, produced total pasture yield improvements over urea similar to those at the higher application rate. The benefits achieved by treating the urea with Agrotain could be similar (on a total yield basis) for both application rates, as in either case the Agrotain is providing the same extra $5-10$ days of urea uptake. It is possible that at $30 \mathrm{~kg} \mathrm{~N} /$ ha, $\mathrm{N}$ uptake is already maximised in this $5-10$ day period, meaning that there is no extra advantage over urea achieved by applying more SustaiN at the $60 \mathrm{~kg} \mathrm{~N} /$ ha application rate.

The fact that, despite only a $19 \%$ improvement in fertiliser $\mathrm{N}$ uptake (averaged across the sites), there was a $44 \%$ improvement in $\mathrm{N}$ response, supports the improved energy theory. It suggests that the pasture is not only taking up more $\mathrm{N}$ as a result of faster uptake and reduced losses, but is also able to more effectively convert this into pasture growth.

\section{Economic assessment}

Whilst the two trials in this study have shown that there is considerable potential for improving pasture yield by using Sustain instead of standard urea, for the technology to be used by farmers, it must be demonstrated to be economically beneficial. Currently SustaiN is priced at a $22 \%$ premium over urea, $(\$ 605$ vs $\$ 495)$. At a current milk solid payout of $\$ 4.07 / \mathrm{kg}$ MS, SustaiN would only have to improve the typical response achieved with urea $(15 \mathrm{~kg} \mathrm{DM} / \mathrm{ha}$ per $\mathrm{kg} \mathrm{N}$ applied/ha) by $6 \%$ (i.e. to $15.9: 1$ ) to cover the extra cost of the fertiliser. This is because the dominant factor determining the cost effectiveness of fertiliser is the response rate, or expressed another way, the extra kg DM grown which can be turned into farm products.

It is possible to calculate the cost-benefits of using SustaiN instead of urea by using the trial results from this study. At the $120 \mathrm{~kg} \mathrm{~N} / \mathrm{ha}$ annual application rate (30 $\mathrm{kg} \mathrm{N} / \mathrm{ha}$ per application), SustaiN produced an extra $1660 \mathrm{~kg} \mathrm{DM} / \mathrm{ha}$ (averaged across the two sites), for a premium of $\$ 28.69 /$ ha ( $\$ 157.82$ for SustaiN vs. $\$ 129.13$ for the same amount of urea). Assuming a milk payout of $\$ 4.07$ and a conversion efficiency of $12 \mathrm{~kg}$ $\mathrm{DM} / \mathrm{kg} \mathrm{MS}$, the extra $1660 \mathrm{~kg} \mathrm{DM} /$ ha would produce an extra $138 \mathrm{~kg} \mathrm{MS} / \mathrm{ha}$ with a value of $\$ 563$, leaving a net margin of $\$ 534 / \mathrm{ha}$. If the same calculation is made for the $240 \mathrm{~kg} \mathrm{~N} / \mathrm{ha}$ annual application rate data $(60 \mathrm{~kg}$ $\mathrm{N} /$ ha per application), the extra $1375 \mathrm{~kg} \mathrm{DM} /$ ha will give a net margin of $\$ 408 /$ ha over the equivalent rate of urea. These examples highlight the substantial economic advantages achievable by using SustaiN instead of urea, and also the relative insignificance of the extra cost of fertiliser in comparison to the extra revenue generated by the extra production.

\section{Conclusions}

Both experiments demonstrated substantial increases in annual pasture production, resulting from the use of Agrotain-treated urea (SustaiN) instead of urea. These increases have been demonstrated to be highly profitable for the farmer. The mechanisms responsible for the increased fertiliser efficiency are not yet fully understood, and the relative importance of possible contributing factors including the effect of soil pasture species and environmental factors on leaching and gaseous losses and increased $\mathrm{N}$ uptake, and the more efficient use of that $\mathrm{N}$ due to the form of uptake are being investigated. 


\section{REFERENCES}

Ball, P.R.; Field, T.R.O. 1982. Responses to nitrogen as affected by pasture characteristics, season and grazing management. pp. 45-64. In: Nitrogen fertiliser in New Zealand agriculture. Ed. Lynch, P.B.

Ball, P.R.; Crush, J.R. 1985. Prospects for increasing symbiotic nitrogen fixation in temperate grasslands. pp 56-60. In: Proceedings of the XV International Grassland Congress.

Black, A.S.; Sherlock, R.R.; Smith, N.P.; Cameron, K.C.; Goh, K.M. 1985. Effects of form of nitrogen, season, and urea application rate on ammonia volatilisation from pastures. New Zealand Journal of Agricultural Research 28: 469-474.

Castle, M.L. 2004. The physiology of nitrogen in white clover (Trifolium repens L.) at low temperatures. Unpubl. PhD thesis. RMIT University, Melbourne. $226 \mathrm{pp}$.

Ledgard, S.F.; Penno, J.W.; Sprosen, M.S. 1999. Nitrogen inputs and losses from clover/ryegrass pastures grazed by dairy cows, as affected by nitrogen fertiliser application. Journal of Agricultural Science, Cambridge 132: 215-225.

Parliamentary Commissioner for the Environment 2004: Growing for good: Intensive farming sustainability and New Zealand's environment. Wellington: Parliamentary Commissioner for the Environment. 236 pp.

Quin, B.F.; Blennerhassett, J.D.; Zaman, M. 2005. The use of urease inhibitor-based products to reduce nitrogen losses from pasture. pp 288-304 In:
Proceedings of the Workshop "Developments in Fertiliser Application Technologies and Nutrient Management" 9-10 February 2005. Eds. Currie, L.D.;Hanly, J.A. Fertiliser and Lime Research Centre Occasional Report No. 18. Massey University, Palmerston North.

Quin, B.F.; Rowarth, J.S.; Blennerhassett, J.D.; Crush, J.R.; Cornforth I.S. 2006. Removing the barriers to improved response to fertiliser N - the plant's perspective. In: Proceedings of the Workshop "Implementing Sustainable Nutrient Management Strategies in Agriculture" 8-9 February 2006. Eds. Currie, L.D.; Hanly, J.A. Fertiliser and Lime Research Centre Occasional Report No. 19. Massey University, Palmerston North, (in press).

Theobald, P.W.; Ball, P.R. 1984. Nitrogen lost by ammonia volatilisation, and the effectiveness of urea and ammonium sulphate fertilisers. Proceedings of the New Zealand Grassland Association 45: 236238.

Watson, C.J. 2000. Urease activity and inhibitors principles and practice. pp 39 In: The International Fertiliser Society, Proceedings No. 454.

Zaman, M.; Nguygen, L.; Blennerhassett, J.D.; Quin, B.F. 2005. Increasing the utilisation of urea fertiliser by pasture. pp 276-284 In: Proceedings of the Workshop "Developments in Fertiliser Application Technologies and Nutrient Management" 9-10 February 2005. Eds. Currie, L.D.; Hanly, J.A. Fertiliser and Lime Research Centre Occasional Report No. 18. Massey University, Palmerston North. 